\title{
Synergistic Effect of the Lactoperoxidase System and Cinnamon Essential Oil on Total Flora and Salmonella Growth Inhibition in Raw Milk
}

\author{
Chiraz Abbes $\mathbb{D}$, Ahlem Mansouri, and Ahmed Landoulsi $\mathbb{i}$ \\ Laboratory of Biochemistry and Molecular Biology, Faculty of Sciences, Risks Related to Environmental Stress, \\ Struggle and Prevention (UR17ES20), University of Carthage, The Ministry of Higher Education and Scientific Research, \\ Zarzouna, 7003 Bizerte, Tunisia
}

Correspondence should be addressed to Chiraz Abbes; chiraz.abbes@gmail.com

Received 18 September 2017; Revised 25 December 2017; Accepted 19 March 2018; Published 23 April 2018

Academic Editor: Maria Rosaria Corbo

Copyright (C) 2018 Chiraz Abbes et al. This is an open access article distributed under the Creative Commons Attribution License, which permits unrestricted use, distribution, and reproduction in any medium, provided the original work is properly cited.

Despite its antibacterial and antipathogenic effects, the heat treatment of milk induces undesirable changes that can be noted in the overall properties of ultrahigh temperature (UHT) milk, such as changes in nutritional and organoleptic properties. Our goal is to find new nonthermal antibacterial technologies for the preservation of raw milk (RM). This study investigates the possible synergistic effect of using a combination of the lactoperoxidase system (LS) and $3 \mu \mathrm{g} \mathrm{mL}^{-1}$ of cinnamon essential oil (cinnamon EO) to inactivate the total flora of milk and Salmonella Hadar (S. Hadar). The LS was activated with $30 \mathrm{mg} \mathrm{L}^{-1}$ sodium percarbonate and $14 \mathrm{mg} \mathrm{L}^{-1}$ of sodium thiocyanate. Using this approach, we obtained a synergistic effect with a complete inhibition of the activity of the total flora of the milk and $S$. Hadar after 12 hours at $25^{\circ} \mathrm{C}$. In addition, the attainment of synergy was defined when the inhibitory effect of the two compounds together was greater than the effect observed by each compound added alone. Moreover, the monitoring of the synergistic effect at $4^{\circ} \mathrm{C}$ for 5 days showed complete inhibition of total flora for 3 days and for $S$. Hadar it was up to 5 days. To summarize, the current study clearly identified a new inhibitory combination that may be used in food-based applications.

\section{Introduction}

Salmonella enterica has been identified as a food-borne pathogen of great importance in recent years. It is a major problem for human health around the world $[1,2]$. A study conducted in Tunisia from 1994 to 2004 showed that Salmonella enterica serovar Hadar is a bacteria that is very often present in milk and dairy products $[3,4]$.

Heat treatment is a very effective technique for the destruction of pathogenic microorganisms, but this technique can cause changes in the nutritional and organoleptic properties of the milk $[5,6]$. This is the reason why several efforts have been made to develop novel nonthermal processing technologies [7], such as the use of, for example, lactoperoxidase which is a bioactive peptide naturally occurring in bovine milk naturally in bovine milk [8].

The lactoperoxidase system (LS) is a natural antimicrobial system of milk $[9,10]$. The LS consists of three compounds: the enzyme lactoperoxidase, hydrogen peroxide $\left(\mathrm{H}_{2} \mathrm{O}_{2}\right)$, and thiocyanate $\left(\mathrm{SCN}^{-}\right)[11,12]$. Its use has been suggested as an antimicrobial agent for the preservation of food for safe human consumption [13-15].

In hot countries, where refrigeration is not possible for the preservation of raw milk, it would be useful to activate the LS in the milk just after milking, allowing its natural preservation until its delivery to the factory [16]. Several studies have shown the effectiveness of this antimicrobial system against several germs, such as Salmonella enterica [17] and Escherichia coli O157:H7 [18].

In Europe, essential oils (EOs), which are natural extracts of plants, are classified as flavourings (European Decision 2002/113/EC of 23 January 2002, notified under document number C (2002) 88). Moreover, the US Food and Drug Administration consider EOs as generally recognised as safe compounds (GRAS).

The cinnamon essential oil (cinnamon EO) is very rich in cinnamaldehyde, which is the major component found in this oil [19]. Several studies have shown that cinnamaldehyde has 
powerful antioxidant [20], anti-inflammatory [21], anticancer $[22,23]$ properties and has antibacterial properties against various microorganisms in milk [24, 25]. Recent studies have shown that cinnamon EO inhibits the growth of several bacteria, such as E. coli O157:H7 [26, 27] and Salmonella typhimurium [28]. Another interesting work showed that cinnamaldehyde has an antidepressant activity in animals [29].

Nowadays, the consumer is increasingly interested in finding natural substances in their diet [30]. Despite the high efficacy of essential oils against food-borne pathogens, their use has been limited. Indeed, to have an antimicrobial effect, it is necessary to add high concentrations of essential oils [30, 31]. This can have a negative effect on the organoleptic quality of the food. Only a few approaches have been proposed to reduce the amount of essential oils required and reduce sensory effects $[32,33]$. For this reason, combinations with other compounds may be promising alternatives [34]. One solution involves combining plant extracts with a bioactive protein in the milk.

The aim of this work is to study the combined effect of the LS and cinnamon EO, looking for a possible synergism to inhibit the total flora of milk and the pathogenic $S$. Hadar in raw milk.

\section{Materials and Methods}

2.1. Antimicrobial Substances. Essential oil of cinnamon (Cinnamomum zeylanicum from bark; originated in Cylan-Sri Lanka) was obtained from Chemical Abstracts Service (CAS) (registry number 84649-98-9) and cinnamaldehyde (a final percentage of $72.08 \%$ ) was supplied by Esperis (Milan, Italy).

2.2. Bacterial Strain. The bacterial strain used, Salmonella enterica serovar Hadar, was selected at the Pasteur Institute, Tunisia. This is Salmonella Hadar, isolate 63, classified under number 6,8:z10:e,n,x [35].

2.3. Source of Milk. Our supplier of raw milk was the EL BADER Group, Bizerte, Tunisia.

2.4. The Effect of the LS in Combination with Cinnamon EO on Actively Growing Cells of Total Flora of Milk. Into $10 \mathrm{~mL}$ of raw milk, we activated the LS and added $3 \mu \mathrm{g} \mathrm{mL}^{-1}$ of cinnamon EO (the concentration of which, when mixed with the activated LS, resulted in the total inhibition of the total flora of raw milk) at the initial time. The LS was activated with $30 \mathrm{mg} \mathrm{L}^{-1}$ of sodium percarbonate $2 \mathrm{Na}_{2} \mathrm{CO}_{3} \cdot 3 \mathrm{H}_{2} \mathrm{O}_{2}$ and $14 \mathrm{mg} \mathrm{L}^{-1}$ of sodium thiocyanate (NaSCN) [16].

The sodium percarbonate is recommended by the codex as it leads to a slower release of hydrogen peroxide. Under these experimental conditions the $\mathrm{OSCN}^{-}$ion is the main antibacterial product $[16,36]$.

For this experiment, we have prepared four controls. The first control contained only raw milk. In the second control, we activated the LS in raw milk. The third control contained raw milk with $3 \mu \mathrm{g} \mathrm{mL}^{-1}$ of cinnamon EO. In the fourth control, we added $30 \mathrm{mg} \mathrm{L}^{-1}$ of sodium percarbonate in raw milk. The preparations were monitored at $25^{\circ} \mathrm{C}$ for 12 hours.
TABLE 1: Efficacy of the lactoperoxidase system and cinnamon essential oil in inhibiting the growth of total flora of milk.

\begin{tabular}{lcc}
\hline & $\begin{array}{c}\text { Number of total flora } \\
\text { of milk } \\
\left(\log _{10} \text { CFU mL }\right.\end{array}$ & $\begin{array}{c}\text { Number of total flora } \\
\text { of milk }\end{array}$ \\
at the initial time & $\begin{array}{c}\left(\log _{10} \text { CFU mL } \mathrm{mL}^{-1}\right) \\
\text { after } 12 \text { hours }\end{array}$ \\
\hline $\mathrm{RM}$ & $6.39 \pm 0.01$ & $9.37 \pm 0.10$ \\
$\mathrm{RM}+\mathrm{LS}$ & $6.39 \pm 0.01$ & $6.72 \pm 0.30$ \\
$\mathrm{RM}+\mathrm{Ci}$ & $6.39 \pm 0.01$ & $6.04 \pm 0.06$ \\
$\mathrm{RM}+\mathrm{LS}+\mathrm{Ci}$ & $6.39 \pm 0.01$ & 0.00 \\
\hline
\end{tabular}

$\mathrm{RM}=$ raw milk; $\mathrm{Ci}=$ cinnamon essential oil at $3 \mu \mathrm{g} \mathrm{m}^{-1} ; \mathrm{LS}=$ activation of the lactoperoxidase system with $30 \mathrm{mg} \mathrm{L}^{-1}$ of sodium percarbonate and $14 \mathrm{mg} \mathrm{L}^{-1}$ of sodium thiocyanate.

All the experiments were repeated three times. Replications were done to determine the total viable number. LuriaBertani medium (Difco) was used for enumeration of total bacteria in raw milk. During the 12 hours of the experiment the LS remained active [16].

2.5. The Effect of the LS in Combination with Cinnamon EO on Actively Growing Cells of S. Hadar in Milk. A volume of $10 \mathrm{~mL}$ of raw milk (in the absence of $S$. Hadar) was inoculated with $S$. Hadar to a final concentration of $8 \times 10^{5} \mathrm{CFU} \mathrm{mL}^{-1}[17,37]$. We activated the LS (as previously described) and added $3 \mu \mathrm{g} \mathrm{mL}^{-1}$ of cinnamon EO. Four controls were prepared. The first control contained raw milk with $S$. Hadar. The second control contained $S$. Hadar with activators of the LS in raw milk. The third control contained raw milk with $S$. Hadar with cinnamon EO (without activating the LS). The fourth control contained $S$. Hadar with $30 \mathrm{mg} \mathrm{L}^{-1}$ of sodium percarbonate in raw milk. The preparations were monitored at $25^{\circ} \mathrm{C}$ for 12 hours. All the experiments were repeated three times. Replications were done to determine the amount of $S$. Hadar in raw milk. SS agar (Difco) was used for enumeration of total bacteria in raw milk. All of the flasks prepared above were stored at $4^{\circ} \mathrm{C}$ for 7 days. Bacteria were counted every day as explained above.

2.6. Statistical Analysis. Data were analysed using one-way analysis of variance (ANOVA), with Tukey's test (HSD) (STATISTICA version 6.0 for Microsoft Windows). Data were found to be significant at $p<0.05$ relative to the control milk.

\section{Results}

3.1. The Effect of the LS in Combination with Cinnamon EO on Actively Growing Cells of Total Flora of Milk. We studied the antibacterial activity of $3 \mu \mathrm{g} \mathrm{mL}^{-1}$ of cinnamon EO and the LS, both alone and in combination, at $25^{\circ} \mathrm{C}$ over a period of 12 hours in relation to the total flora of milk. The data reported in Table 1 indicate that, after 12 hours of growth with the LS activated, the total flora in the milk rose from $6.39 \log _{10}$ to $6.72 \log _{10} \mathrm{CFU} \mathrm{mL} \mathrm{m}^{-1}$, compared to $9.37 \log _{10} \mathrm{CFU} \mathrm{mL}^{-1}$ for the control $(p<0.05)$. Under the same conditions and in only the presence of cinnamon EO in the milk, the total 
TABLE 2: Efficacy of the lactoperoxidase system and cinnamon essential oil in inhibiting the growth of Salmonella enterica Hadar.

\begin{tabular}{lcc}
\hline & $\begin{array}{c}\text { Number of } S . \text { Hadar } \\
\left(\log _{10} \text { CFU mL } \mathrm{mL}^{-1}\right) \\
\text { at the initial time }\end{array}$ & $\begin{array}{c}\text { Number of } S \text {. Hadar } \\
\left(\log _{10} \text { CFU mL } \mathrm{mL}^{-1}\right) \\
\text { after } 12 \text { hours }\end{array}$ \\
\hline $\mathrm{RM}+\mathrm{S}$ & $5.9 \pm 0.20$ & $10.05 \pm 0.07$ \\
$\mathrm{RM}+\mathrm{S}+\mathrm{LS}$ & $5.9 \pm 0.20$ & $7.25 \pm 0.08$ \\
$\mathrm{RM}+\mathrm{S}+\mathrm{Ci}$ & $5.9 \pm 0.20$ & $4.94 \pm 0.12$ \\
$\mathrm{RM}+\mathrm{S}+\mathrm{LS}+\mathrm{Ci}$ & $5.9 \pm 0.20$ & 0.00 \\
\hline
\end{tabular}

$\mathrm{RM}=$ raw milk; $\mathrm{S}=$ Salmonella enterica Hadar $; \mathrm{Ci}=$ cinnamon essential oil at $3 \mu \mathrm{g} \mathrm{mL}^{-1}$; LS = activation of the lactoperoxidase system with $30 \mathrm{mg} \mathrm{L}^{-1}$ of sodium percarbonate and $14 \mathrm{mg} \mathrm{L}^{-1}$ of sodium thiocyanate.

flora decreased from $6.39 \log _{10}$ to $6.04 \log _{10} \mathrm{CFU} \mathrm{mL} \mathrm{L}^{-1}$. The addition of cinnamon EO induces an insignificant inhibition of $0.35 \log _{10}$ units $(p>0.05)$ (Table 1). After adding the LS together with cinnamon EO at the start, we observed a complete inhibition of total flora of milk after 12 hours of growth $(p<0.05)$. The fourth control did not show any relevant antimicrobial activity.

\subsection{The Effect of the LS in Combination with Cinnamon} EO on Actively Growing Cells of S. Hadar. In this work, we studied the antibacterial activity of the LS and $3 \mu \mathrm{g} \mathrm{mL}^{-1}$ of cinnamon EO, both alone and in combination, against $S$. Hadar at $25^{\circ} \mathrm{C}$ over a period of 12 hours. In the control milk, $S$. Hadar increased from $5.9 \log _{10}$ to $10.05 \log _{10} \mathrm{CFU} \mathrm{mL} \mathrm{m}^{-1}$. After activating the LS, the number of $S$. Hadar increased $5.9 \log _{10}$ to $7.25 \log _{10} \mathrm{CFU} \mathrm{mL} L^{-1}(p<0.05)$. After adding $3 \mu \mathrm{g} \mathrm{mL}^{-1}$ of cinnamon EO, counts of $S$. Hadar decreased to $4.94 \log _{10} \mathrm{CFU} \mathrm{mL} L^{-1}(p>0.05)$ (Table 2). After combining the LS together with cinnamon EO, the number of bacteria decreased gradually for 6 hours and then fell rapidly and we observed a complete inhibition of germs after 9 hours of growth $(p<0.05)$. The fourth control did not show any relevant antimicrobial activity.

3.3. Monitoring the Synergistic Effect at $4^{\circ} \mathrm{C}$. According to Figure 1, the LS with $3 \mu \mathrm{g} \mathrm{mL}^{-1}$ of cinnamon EO added at the initial time showed a synergistic and lasting bactericidal effect which, after 3 days at $4^{\circ} \mathrm{C}$, resulted in no detectable cells of total flora and $S$. Hadar in the milk.

After 4 days of growth, we observed the appearance of $4.2 \log _{10} \mathrm{CFU} \mathrm{mL} \mathrm{L}^{-1}$ of total flora of milk and $4.6 \log _{10} \mathrm{CFU} \mathrm{mL} \mathrm{m}^{-1}$ after 5 days of growth. On the other hand, no $S$. Hadar was observed up to the end of the experiment.

\section{Discussion}

The results of the present work show that the combination of the LS and cinnamon EO significantly reinforced the inhibitory effect against the total flora of milk and $S$. Hadar in raw milk after 12 hours at $25^{\circ} \mathrm{C}$. The activation of the LS alone or the addition of cinnamon EO alone does not show a significant decrease in the number of germs. The degree of synergy was defined when the inhibitory effect of the two compounds together was greater than the effect observed by

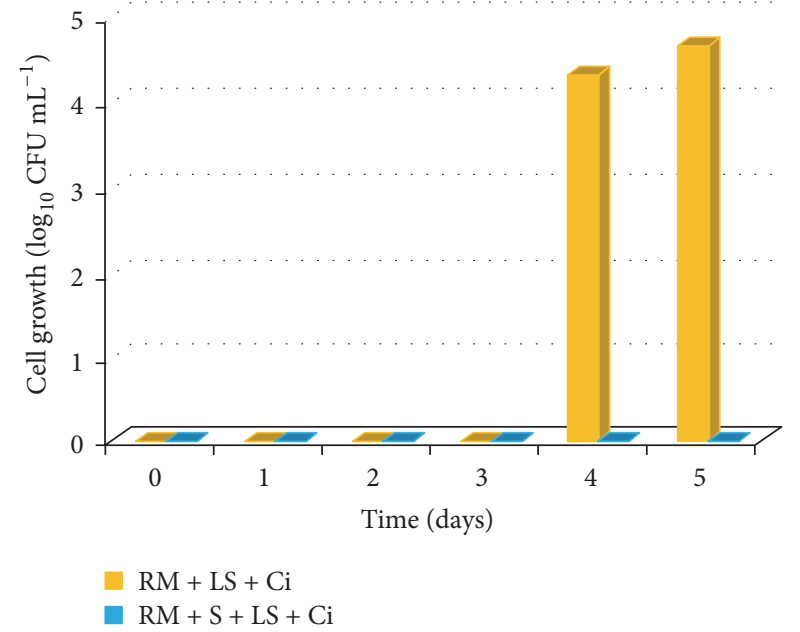

FIGURE 1: Monitoring the synergistic effect at $4^{\circ} \mathrm{C}$. RM = raw milk; $\mathrm{Ci}=$ cinnamon essential oil at $3 \mu \mathrm{g} \mathrm{mL}^{-1}$; LS = activation of the lactoperoxidase system with $30 \mathrm{mg} \mathrm{L}^{-1}$ of sodium percarbonate and $14 \mathrm{mg} \mathrm{L}^{-1}$ of sodium thiocyanate.

each compound added alone [38]. This study was the first time a possible synergy between the LS and essential oil had been investigated.

Moreover, several studies have examined combinations of different techniques to inhibit food-borne pathogens. The LS has been used in synergy with other nonthermal methods in the preservation of food, such as pulsed electric fields and high hydrostatic pressure [39]. The LS has also been used in combination with bioactive molecules in food, such as nisin, reuterin, and Laminaria [40, 41]. An antimicrobial effect has also been shown with cinnamon EO acting synergistically with other methods, for example, with gamma irradiation [42] or nisin [43].

To obtain a synergistic effect, several antimicrobial modes of action are possible, such as an inhibition of the activity of many enzymes belonging to different metabolic pathways or weakening the bacterial cellular structure [44]. We wanted to understand the mechanism that induced a synergistic inhibitory effect between the LS and cinnamon EO system. Many studies have been devoted to the antimicrobial activity and mechanism of action of the essential oils of plants. Studies have shown that cinnamaldehyde can damage the cytoplasmic membrane due to its action on the proton motive force, by the leakage of small ions without the leakage of ATP [45]. Other studies suggest that the cell membrane is involved in the toxic action of cinnamon EO against Escherichia coli O157:H7 [46]. According to the work of Visvalingam et al. 2013 [26], the antimicrobial effect of cinnamon EO is principally attributable to its carbonyl aldehyde group. Indeed, they showed that different concentrations of cinnamaldehyde caused elongation of Escherichia coli cells and delayed growth [47]. Cinnamaldehyde not only does exhibit toxic effects on cytoplasmic membranes [48], but also inhibits biochemical pathways [49]. The LP is also toxic to the cytoplasmic membrane [50]. Indeed, lactoperoxidase catalyzes the oxidation of thiocyanate by $\mathrm{H}_{2} \mathrm{O}_{2}$ to hypothiocyanite anion $\left(\mathrm{OSCN}^{-}\right)$ 
[51, 52], which, in turn, oxidizes the sulphydryl ( $\mathrm{SH}$ ) groups in the bacterial cytoplasmic membrane $[9,53]$. The enhanced effect of cinnamon EO and the LS on growing cells of $S$. Hadar and total flora of milk is consistent with previous research. The synergistic effect of LS and cinnamon EO can be explained by their simultaneous effects on the cytoplasmic membrane.

The results obtained from monitoring the synergistic effect at $4^{\circ} \mathrm{C}$ showed that there was a bactericidal effect against $S$. Hadar. This led us to conclude that the LS and cinnamon EO probably have a synergistic bactericidal effect on $S$. Hadar and a synergistic bacteriostatic behaviour regarding the total flora in milk. Expanding on this, it is known that the LS have bactericidal and bacteriostatic activities regarding a wide range of susceptible microorganisms. This depends on the conditions of the experiment, such as temperature, $\mathrm{pH}$, and incubation time [54,55]. The effect of the LS can be bactericidal against Gram-negative bacteria, such as salmonellae, or bacteriostatic against Gram-positive bacteria, like lactobacilli.

In fact, this difference may be due to the cytoplasmic membrane of Gram-positive bacteria which seems more resistant to the effect of the LS than Gram-negative species. The LS may also inhibit the growth of some catalase-positive Gram-negative organisms [56].

Despite the fact that LS and cinnamon EO are natural food preservatives, their use remains limited, since their spectrum of antimicrobial activity is not very wide [57]. As we showed in this study, the antibacterial effect of cinnamon EO and the LS can be enhanced if these compounds are combined. In addition, it is a nonthermal technology for the biopreservation of raw milk. Also, it ensures the safety of raw milk from the undesirable changes that can be detected in the organoleptic quality and the nutritional properties of ultrahigh temperature processed (UHT) milk.

\section{Conclusion}

In this work, we studied the antibacterial effect of the combination of the LS and cinnamon EO at $3 \mu \mathrm{g} \mathrm{mL} \mathrm{L}^{-1}$ against total flora of milk and a food-borne pathogen $S$. Hadar. The results showed that a synergistic antimicrobial effect was obtained. Regarding both total flora and $S$. Hadar, we demonstrated complete inhibition of the germs studied for 3 days at $4^{\circ} \mathrm{C}$. This work has prompted further studies to develop the use of natural antimicrobials and nonthermal preservation to maintain the good nutritional properties of raw milk, while ensuring the microbiological safety and nutritional properties, to produce milk flavoured with a cinnamon taste.

\section{Conflicts of Interest}

The authors declare that there are no conflicts of interest.

\section{References}

[1] T. Fang, "Bacterial Contamination of Ready-to-Eat Foods," in Reviews in Food and Nutrition Toxicity, Volume 4, vol. 20051045 of Resource Management, CRC Press, 2005.
[2] European Food Safety Authority, EFSA explains zoonotic diseases: Food-borne zoonotic diseases, 2009, Eur. Surveill. 1-4.

[3] I. Abbassi-Ghozzi, S. Hammami, R. Ben Aissa, J. MartinezUrtaza, A. Boudabous, and M. Gtari, Pulsed-field gel electrophoresis, plasmid profile and antimicrobial resistance pattern of Salmonella typhimurium isolated from human and retail meats, 2012.

[4] R. B. Aissa, N. Al-Gallas, H. Troudi, N. Belhadj, and A. Belhadj, "Trends in Salmonella enterica serotypes isolated from human, food, animal, and environment in Tunisia, 1994-2004," Infection, vol. 55, no. 4, pp. 324-339, 2007.

[5] S. Calligaris, L. Manzocco, M. Anese, and M. C. Nicoli, "Effect of heat-treatment on the antioxidant and pro-oxidant activity of milk," International Dairy Journal, vol. 14, no. 5, pp. 421-427, 2004.

[6] I. Seiquer, C. Delgado-Andrade, A. Haro, and M. P. Navarro, "Assessing the effects of severe heat treatment of milk on calcium bioavailability: In vitro and in vivo studies," Journal of Dairy Science, vol. 93, no. 12, pp. 5635-5643, 2010.

[7] S. Mukhopadhyay and R. Ramaswamy, "Application of emerging technologies to control Salmonella in foods: A review," Food Research International, vol. 45, no. 2, pp. 666-677, 2012.

[8] D. Schlorke, J. Atosuo, J. Flemmig, E.-M. Lilius, and J. Arnhold, "Impact of cyanogen iodide in killing of Escherichia coli by the lactoperoxidase-hydrogen peroxide-(pseudo)halide system," Free Radical Research, vol. 50, no. 12, pp. 1287-1295, 2016.

[9] K. D. Kussendrager and A. C. van Hooijdonk, "Lactoperoxidase: physico-chemical properties, occurrence, mechanism of action and applications," British Journal of Nutrition, vol. 84, no. S1, 2000.

[10] A. K. Singh, M. L. Smith, S. Yamini et al., "Bovine carbonyl lactoperoxidase structure at $2.0 \AA$ resolution and infrared spectra as a function of $\mathrm{pH}, "$ The Protein Journal, vol. 31, no. 7, pp. 598608, 2012.

[11] C. Abbes, A. Mansouri, M. Hadded, . L, and A. oulsi, "Optimizing antimicrobial activity of the bovine lactoperoxidase system against Salmonella enterica Hadar, a causative agent of human gastroenteritis in Tunisia," African Journal of Microbiology Research, vol. 7, no. 22, pp. 2719-2723, 2013.

[12] L. W. T. Fweja, M. J. Lewis, and A. S. Grandison, "Alternative strategies for activation of the natural lactoperoxidase system in cows' milk: Trials in Tanzania," Journal of Dairy Research, vol. 74, no. 4, pp. 381-386, 2007.

[13] M. S. Jasour, A. Ehsani, L. Mehryar, and S. S. Naghibi, "Chitosan coating incorporated with the lactoperoxidase system: An active edible coating for fish preservation," Journal of the Science of Food and Agriculture, vol. 95, no. 6, pp. 1373-1378, 2015.

[14] E. M. El-Fakharany, V. N. Uversky, and E. M. Redwan, "Comparative Analysis of the Antiviral Activity of Camel, Bovine, and Human Lactoperoxidases Against Herpes Simplex Virus Type 1," Applied Biochemistry and Biotechnology, vol. 182, no. 1, pp. 294-310, 2017.

[15] M. Kang, H. Park, J.-H. Jun, M. Son, and M. J. Kang, "Facilitated saliva secretion and reduced oral inflammation by a novel artificial saliva system in the treatment of salivary hypofunction," Drug Design, Development and Therapy, vol. 11, pp. 185-191, 2017.

[16] FAO, Guidelines for the Preservation of Raw Milk by the Use of the Lactoperoxidase System, CAC/GL, Rome, 1991.

[17] V. Touch, S. Hayakawa, S. Yamada, and S. Kaneko, "Effects of a lactoperoxidase-thiocyanate-hydrogen peroxide system on 
Salmonella enteritidis in animal or vegetable foods," International Journal of Food Microbiology, vol. 93, no. 2, pp. 175-183, 2004.

[18] A. A. Parry-Hanson, P. J. Jooste, and E. M. Buys, "Relative gene expression in acid-adapted Escherichia coli O157:H7 during lactoperoxidase and lactic acid challenge in Tryptone Soy Broth," Microbiological Research, vol. 165, no. 7, pp. 546-556, 2010.

[19] China Pharmacopeia Commission, Pharmacopoeia of the People's Republic of China, vol. 1, Chinese Medical Science and Technology Press, Beijing, China, 2010, 63-127.

[20] M. A. Murcia, I. Egea, F. Romojaro, P. Parras, A. M. Jiménez, and M. Martínez-Tomé, "Antioxidant Evaluation in Dessert Spices Compared with Common Food Additives. Influence of Irradiation Procedure," Journal of Agricultural and Food Chemistry, vol. 52, no. 7, pp. 1872-1881, 2004.

[21] L. K. Chao, K.-F. Hua, H.-Y. Hsu, S.-S. Cheng, J.-Y. Liu, and S.T. Chang, "Study on the antiinflammatory activity of essential oil from leaves of Cinnamomum osmophloeum," Journal of Agricultural and Food Chemistry, vol. 53, no. 18, pp. 7274-7278, 2005.

[22] B. E. Shan, Y. Yoshida, T. Sugiura, and U. Yamashita, "Stimulating activity of Chinese medicinal herbs on human lymphocytes in vitro," International Journal of Immunopharmacology, vol. 21, no. 3, pp. 149-159, 1999.

[23] N. W. Schoene, M. A. Kelly, M. M. Polansky, and R. A. Anderson, "Water-soluble polymeric polyphenols from cinnamon inhibit proliferation and alter cell cycle distribution patterns of hematologic tumor cell lines," Cancer Letters, vol. 230, no. 1, pp. 134-140, 2005.

[24] C. Gupta, A. Kumari, A. P. Garg et al., "Comparative study of cinnamon oil and clove oil in some oral microbiota," Acta Bio Medica, vol. 82, no. 3, pp. 197-199, 2012.

[25] S. Nowotarska, K. Nowotarski, I. Grant, C. Elliott, M. Friedman, and C. Situ, "Mechanisms of Antimicrobial Action of Cinnamon and Oregano Oils, Cinnamaldehyde, Carvacrol, 2,5Dihydroxybenzaldehyde, and 2-Hydroxy-5-Methoxybenzaldehyde against Mycobacterium avium subsp. paratuberculosis (Map)," Foods, vol. 6, no. 9, p. 72, 2017.

[26] J. Visvalingam, J. D. Hernandez-Doria, and R. A. Holley, "Examination of the genome-wide transcriptional response of Escherichia coli O157: H7 to cinnamaldehyde exposure," Applied and Environmental Microbiology, vol. 79, no. 3, pp. 942950, 2013.

[27] L. Sheng, B. Rasco, and M.-J. Zhu, "Cinnamon oil inhibits Shiga toxin type 2 phage induction and Shiga toxin type 2 production in Escherichia coli O157:H7," Applied and Environmental Microbiology, vol. 82, no. 22, pp. 6531-6540, 2016.

[28] V. K. Juneja, U. Gonzales-Barron, F. Butler, A. S. Yadav, and M. Friedman, "Predictive thermal inactivation model for the combined effect of temperature, cinnamaldehyde and carvacrol on starvation-stressed multiple Salmonella serotypes in ground chicken," International Journal of Food Microbiology, vol. 165, no. 2, pp. 184-199, 2013.

[29] R. Sohrabi, N. Pazgoohan, H. R. Seresht, and B. Amin, "Repeated systemic administration of the cinnamon essential oil possesses anti-anxiety and anti-depressant activities in mice," Iranian Journal of Basic Medical Sciences, vol. 20, no. 6, pp. 708714, 2017.

[30] S. Burt, "Essential oils: their antibacterial properties and potential applications in foods-a review," International Journal of Food Microbiology, vol. 94, no. 3, pp. 223-253, 2004.
[31] V. Hulin, A.-G. Mathot, P. Mafart, and L. Dufosse, "Les propriétés anti-microbiennes des huiles essentielles et composés d'arômes,' Sci. Aliments, vol. 18, no. 6, pp. 563-582, 1998.

[32] P.-C. Hsieh, J.-L. Mau, and S.-H. Huang, "Antimicrobial effect of various combinations of plant extracts," Food Microbiology, vol. 18, no. 1, pp. 35-43, 2001.

[33] A. I. Nazer, A. Kobilinsky, J.-L. Tholozan, and F. DuboisBrissonnet, "Combinations of food antimicrobials at low levels to inhibit the growth of Salmonella sv. Typhimurium: A synergistic effect?" Food Microbiology, vol. 22, no. 5, pp. 391-398, 2005.

[34] J. Hilbig, Q. Ma, P. M. Davidson, J. Weiss, and Q. Zhong, "Physical and antimicrobial properties of cinnamon bark oil conanoemulsified by lauric arginate and Tween 80," International Journal of Food Microbiology, vol. 233, pp. 52-59, 2016.

[35] CNR-Slam, National Reference Centre for Salmonella 2007, Institut Pasteur, 2007, Annual Activity Report.

[36] D. A. Dionysius, P. A. Grieve, and A. C. Vos, "Studies on the lactoperoxidase system: reaction kinetics and antibacterial activity using two methods for hydrogen peroxide generation," Journal of Applied Bacteriology, vol. 72, no. 2, pp. 146-153, 1992.

[37] WHO and FAO, Risk Assessments of Salmonella in Eggs and Broiler Chickens, 2002, p. 71.

[38] G. M. Eliopoulos and C. B. Wennersten, "Antimicrobial activity of quinupristin-dalfopristin combined with other antibiotics against vancomycin-resistant enterococci," Antimicrobial Agents and Chemotherapy, vol. 46, no. 5, pp. 1319-1324, 2002.

[39] C. Garcia-Graells, C. Valckx, and C. W. Michiels, "Inactivation of Escherichia coli and Listeria innocua in milk by combined treatment with high hydrostatic pressure and the lactoperoxidase system," Applied and Environmental Microbiology, vol. 66, no. 10 , pp. 4173-4179, 2000.

[40] J. L. Arqués, E. Rodríguez, M. Nuñez, and M. Medina, "Antimicrobial activity of nisin, reuterin, and the lactoperoxidase system on Listeria monocytogenes and Staphylococcus aureus in cuajada, a semisolid dairy product manufactured in Spain," Journal of Dairy Science, vol. 91, no. 1, pp. 71-75, 2008.

[41] K. Shin, M. Nakano, K. Yamauchi, T. Toida, and K. Iwatsuki, "Antibacterial activity of the lactoperoxidase system combined with edible Laminaria hot-water extract as a source of halide ions," Bioscience, Biotechnology, and Biochemistry, vol. 76, no. 2, pp. 404-406, 2012.

[42] F. Lyu, F. Gao, Q. Wei, and L. Liu, "Changes of membrane fatty acids and proteins of Shewanella putrefaciens treated with cinnamon oil and gamma irradiation," Bioresources and Bioprocessing, vol. 4, no. 1, 2017.

[43] S. M. Razavi Rohani, M. Moradi, T. Mehdizadeh, S. S. SaeiDehkordi, and M. W. Griffiths, "The effect of nisin and garlic (Allium sativum L.) essential oil separately and in combination on the growth of Listeria monocytogenes," LWT-Food Science and Technology, vol. 44, no. 10, pp. 2260-2265, 2011.

[44] A. Santiesteban-López, E. Palou, and A. López-Malo, "Susceptibility of food-borne bacteria to binary combinations of antimicrobials at selected aw and pH," Journal of Applied Microbiology, vol. 102, no. 2, pp. 486-497, 2007.

[45] A. O. Gill and R. A. Holley, "Mechanisms of bactericidal action of cinnamaldehyde against Listeria monocytogenes and of eugenol against L. monocytogenes and Lactobacillus sakei," Applied and Environmental Microbiology, vol. 70, no. 10, pp. 5750-5755, 2004.

[46] M. Oussalah, S. Caillet, and M. Lacroix, "Mechanism of action of Spanish oregano, Chinese cinnamon, and savory essential oils 
against cell membranes and walls of Escherichia coli O157:H7 and Listeria monocytogenes," Journal of Food Protection, vol. 69, no. 5, pp. 1046-1055, 2006.

[47] J. Visvalingam and R. A. Holley, “Temperature-dependent effect of sublethal levels of cinnamaldehyde on viability and morphology of Escherichia coli," Journal of Applied Microbiology, vol. 113, no. 3, pp. 591-600, 2012.

[48] C. M. Feniman, V. L. M. Rall, J. T. Doyama, and A. F. Jnior, "Cell enumeration and visualisation by transmission electron microscopy of Lactobacillus rhamnosus treated with cinnamon (Cinnamomum zeylanicum B.) essential oil," Natural Product Research (Formerly Natural Product Letters), vol. 26, no. 18, pp. 1721-1723, 2012.

[49] A. C. Chan, D. Ager, and I. P. Thompson, "Resolving the mechanism of bacterial inhibition by plant secondary metabolites employing a combination of whole-cell biosensors," Journal of Microbiological Methods, vol. 93, no. 3, pp. 209-217, 2013.

[50] B. A. Law and P. John, "Effect of the lactoperoxidase bactericidal system on the formation of the electrochemical proton gradient in E. coli," FEMS Microbiology Letters, vol. 10, no. 1, pp. 67-70, 1981.

[51] K. M. Pruitt, J. Tenovuo, R. W. Andrews, and T. McKane, "Lactoperoxidase-catalyzed oxidation of thiocyanate: polarographic study of the oxidation products," Biochemistry, vol. 21, no. 3, pp. 562-567, 1982.

[52] P. Nagy, G. N. L. Jameson, and C. C. Winterbourn, "Kinetics and mechanisms of the reaction of hypothiocyanous acid with 5-thio-2-nitrobenzoic acid and reduced glutathione," Chemical Research in Toxicology, vol. 22, no. 11, pp. 1833-1840, 2009.

[53] K. Shin, H. Hayasawa, and B. Lönnerdal, "Inhibition of Escherichia coli respiratory enzymes by the lactoperoxidasehydrogen peroxide-thiocyanate antimicrobial system," Journal of Applied Microbiology, vol. 90, no. 4, pp. 489-493, 2001.

[54] H. A. Almehdar, E. M. El-Fakharany, V. N. Uversky, and E. M. Redwan, "Disorder in milk proteins: Structure, functional disorder, and biocidal potentials of lactoperoxidase," Current Protein \& Peptide Science, vol. 16, no. 4, pp. 352-365, 2015.

[55] L. Björck, C. Rosén, V. Marshall, and B. Reiter, "Antibacterial activity of the lactoperoxidase system in milk against pseudomonads and other gram-negative bacteria," Applied Microbiology, vol. 30, no. 2, pp. 199-204, 1975.

[56] V. M. E. Marshall and B. Reiter, "Comparison of the antibacterial activity of the hypothiocyanite anion towards Streptococcus lactis and Escherichia coli," Journal of General Microbiology, vol. 120, no. 2, pp. 513-516, 1980.

[57] P. M. Davidson, F. J. Critzer, and T. Matthew Taylor, "Naturally occurring antimicrobials for minimally processed foods," Annual Review of Food Science and Technology, vol. 4, no. 1, pp. 163-190, 2013. 


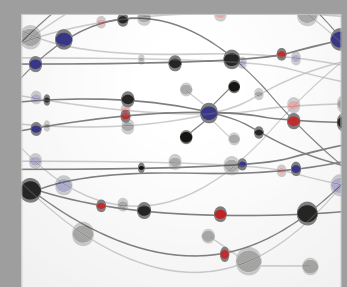

The Scientific World Journal
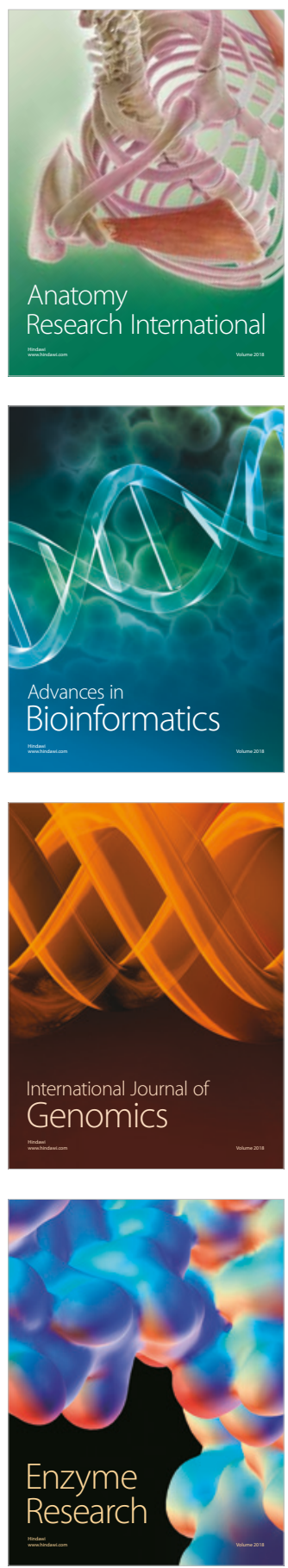
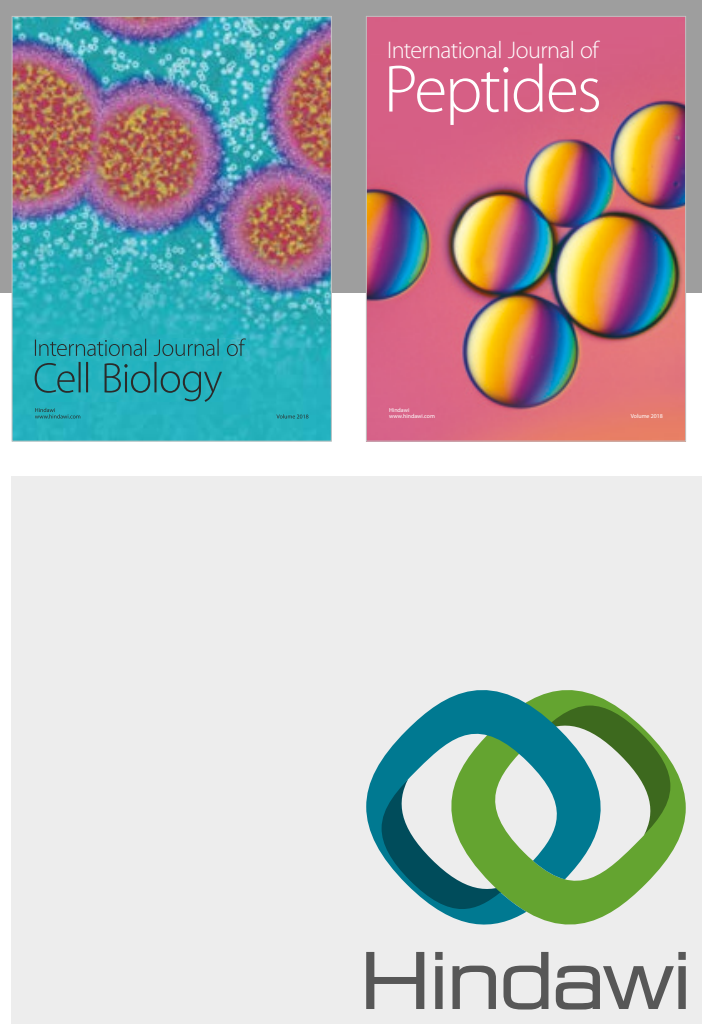

Submit your manuscripts at

www.hindawi.com
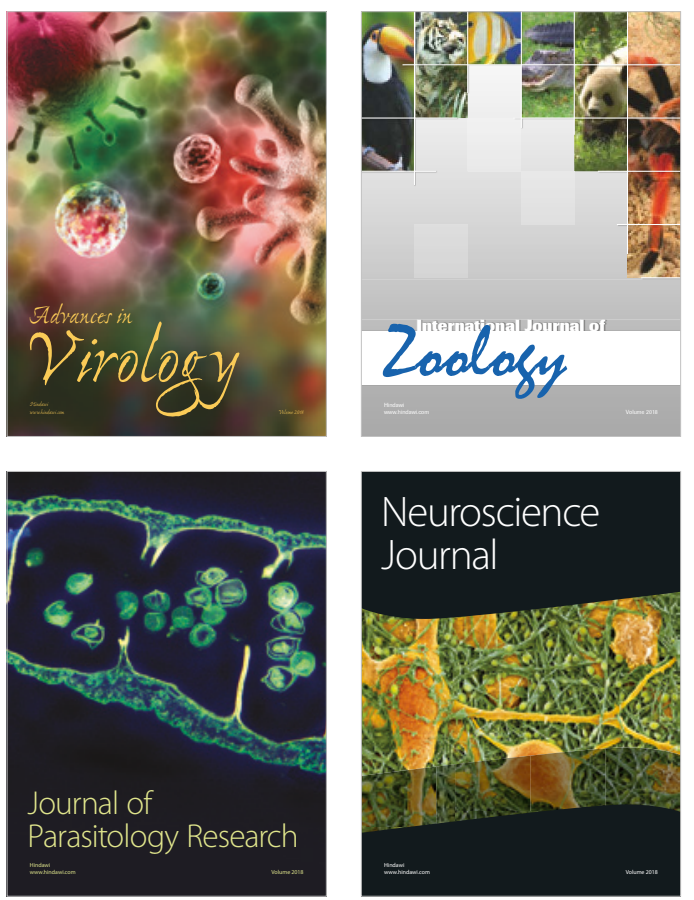
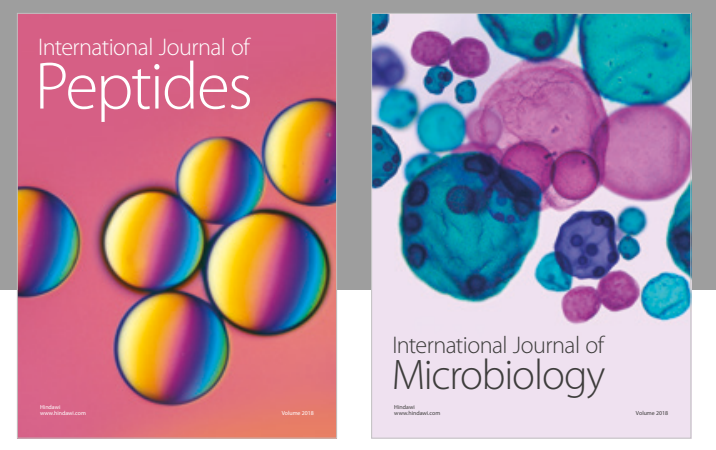

nternational Journal of Microbiology
Journal of
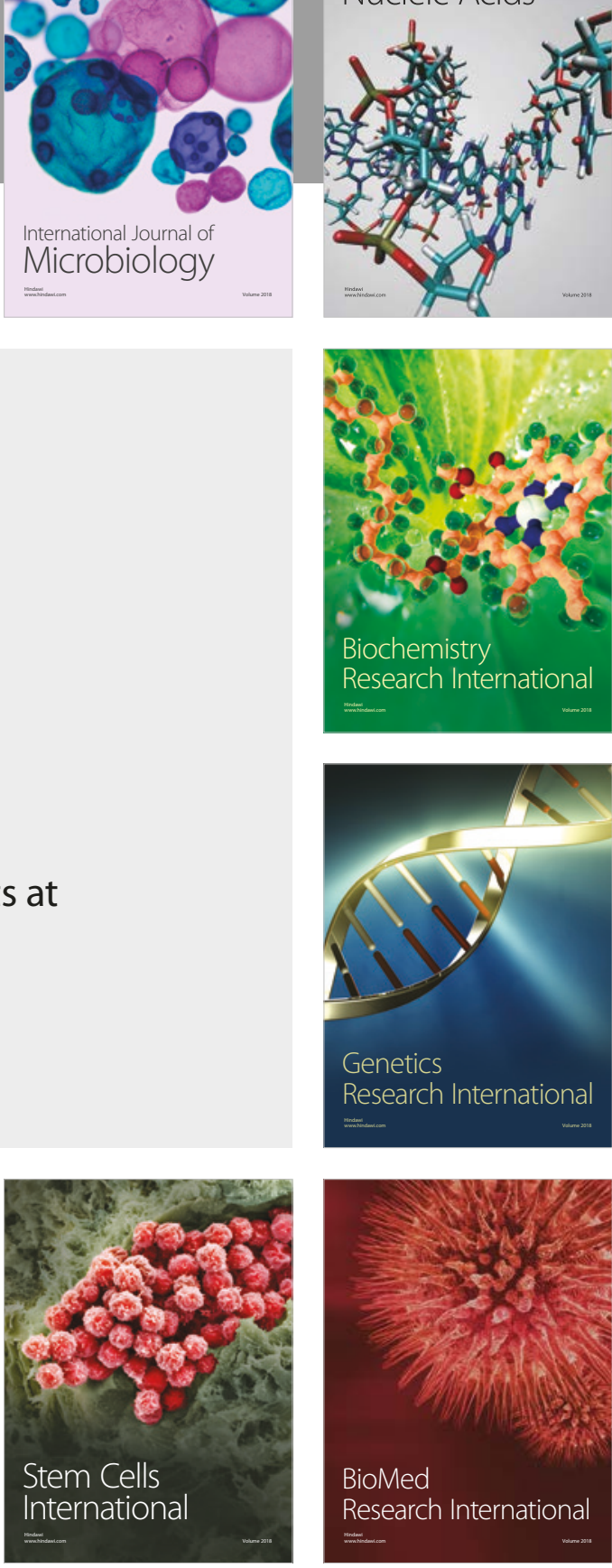
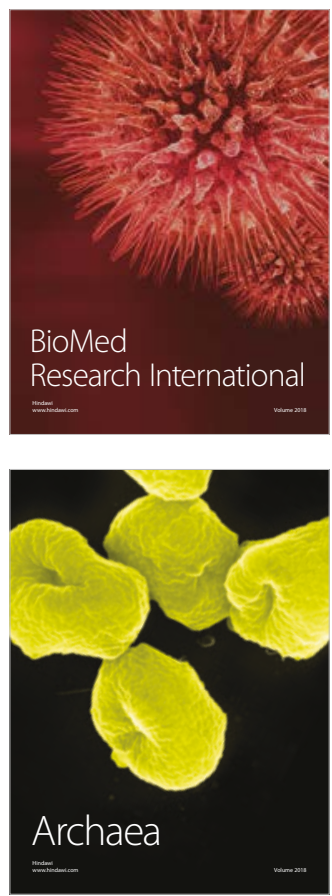